\title{
Use of Learning Video Media to Improve Student Learning Outcomes of Grade 5 Elementary School Thematic Online Learning
}

\section{Danu Dharmoyo}

SDN 2 Dlepih

danoedharmojo@gmail.com

\section{Article History}

accepted 01/11/2020

\begin{abstract}
The purpose of this study was to improve student learning outcomes in thematic learning in grade $V S D$. This research is a classroom action research (PTK) which is carried out in three cycles, each cycle consisting of planning, implementation, observation, and reflection stages. The subjects of this study were 10 grade students of SDN 2 Dlepih in the 2019/2020 academic year. Data collection techniques using observation and tests. Data analysis includes data reduction, data presentation, and drawing conclusions. Research shows that the use of instructional video media can improve student learning outcomes in the subject matter of Theme 3 Sub Theme 2 Learning 2 in class V SDN 2 Dlepih Tirtomoyo in the academic year 2020/2021 as evidenced by the percentage of completeness of learning outcomes in cycle I of $70 \%$ to $90 \%$ in cycle II and become $100 \%$ in cycle III.
\end{abstract}

Keywords: Learning Videos, Thematic, Elementary school students

\section{Abstrak}

Tujuan penelitian ini adalah meningkatkan hasil belajar siswa pada pembelajaran tematik kelas V SD. Penelitian ini merupakan penelitian tindakan kelas (PTK) yang dilaksanakan dalam tiga siklus, setiap siklus terdiri dari tahap perencanaan, pelaksanaan, observasi, dan refleksi. Subjek penelitian ini adalah peserta didik kelas V SDN 2 Dlepih tahun pelajaran 2019/2020 yang berjumlah 10 peserta didik. Teknik pengumpulan data menggunakan observasi dan tes. Analisis data meliputi reduksi data, penyajian data, dan penarikan kesimpulan. Penelitian menunjukkan bahwa penggunaan media video pembelajaran dapat meningkatkan hasil belajar siswa pada materi Tema 3 Sub Tema 2 Pembelajaran 2 di kelas V SDN 2 Dlepih Tirtomoyo tahun pelajaran 2020/2021 yang dibuktikan dengan persentase ketuntasan hasil belajar pada siklus I sebesar $70 \%$ menjadi $90 \%$ pada siklus II dan menjadi $100 \%$ pada siklus III.

Kata kunci: Video Pembelajaran,Tematik, Siswa sekolah dasar

Social, Humanities, and Education Studies (SHEs): Conference Series https://jurnal.uns.ac.id/shes

p-ISSN 2620-9284

e-ISSN 2620-9292 


\section{PENDAHULUAN}

Belajar merupakan suatu proses yang terjadi pada semua orang dan berlangsung seumur hidup. Salah satu indikasi bahwa seseorang telah belajar adalah adanya perubahan tingkah laku dalam dirinya. Perubahan tingkah laku tersebut menyangkut perubahan yang bersifat pengetahuan (kognitif), keterampilan (psikomotor), dan perubahan nilai dan sikap (afektif). Perubahan yang terjadi pada tingkah laku tersebut merupakan perubahan yang bernilai positif. Sehingga tujuan dari belajar tersebut dapat tercapai dengan maksimal. Saat ini Indonesia tengah dihadapkan dengan adanya pandemi Covid-19, hal ini berdampak ke seluruh aspek kehidupan bangsa Indonesia. Salah satunya dunia pendidikan yang mengharuskan melakukan pembelajaran jarak jauh pada daerah yang masuk zona kuning hingga merah terkecuali untuk zona hijau. Dalam melaksanakan tugasnya guru sebagai pembimbing, kolaborator dan juga motivator harus tetap dijalankan walaupun melalui pembelajaran daring. Berbagai media platform digital harus dikuasai oleh seorang guru agar pembelajaran yang dilakukan dapat maksimal. Dengan pembelajaran daring yang dilakukan guru hanya lewat Whatsapp banyak siswa yang kurang aktif dalam pembelajaran. Selain itu kurangnya variasi guru dalam menggunakan media pembelajaran daring membuat siswa cepat bosan dan komunikasi dua arah kurang terlihat dalam pembelajaran.

Situasi dan kondisi ini terlihat jelas ketika guru melaksanakan pembelajaran pada Kelas 5 Tema 3 Subtema 2 Pembelajaran 2 di SDN 2 Dlepih, Tirtomoyo. Dimana ketika guru mengajar melalui chating di aplikasi Whatsapp terlihat banyak siswa yang kurang interaktif saat pembelajaran. Banyak guru yang memilih platform ini karena memang kondisi sekolah di daerah pegunungan dan juga kurangnya pengalaman siswa maupun orangtua.

Hasil pengamatan guru pada pembelajaran Tema 3 Subtema 2 Pembelajaran 2 menggunakan chating WA dari 10 siswa hanya 3 anak (30\%) yang memenuhi criteria ketuntasan minimal. Sebagai guru yang profesional merasa termotivasi untuk melakukan perbaikan, untuk meningkatkan minat belajar siswa. Upaya perbaikan yang peneliti lakukan dengan mengadakan Peneltian Tindakan Kelas (PTK).

Permasalahan tersebut diduga karena : (1) Guru belum menggunakan metode pembelajaran tematik yang bervariasi (2) Kelemahan guru dalam pembuatan dan pemanfaatan media pembelajaran (3) Kurangnya minat siswa dalam mengikuti pembelajaran daring (4) Kurannya daya dukung orang tua dan lingkungan terhadap pelaksanaan pembelajaran daring.

Penulis mengidentifikasi bahwa media pembelajaran yang digunakan menjadi permasalahan utama dalam meningkatkan hasil belajar siswa. Media adalah perantara atau pengantar pesan dari pengirim ke penerima pesan (Sadiman, 2010:6). Media adalah komponen sumber belajar atau wahana fisik yang mengandung materi instrusional di lingkungan siswa yang dapat merangsang siswa untuk belajar (Arsyad, 2014:4). Boove (dalam Ena, 2007) menyatakan bahwa media adalah sebuah alat yang berfungsi untuk menyampaikan pesan pembelajaran. Pembelajaran adalah sebuah komunikasi antara pembelajar, pengajar, dan bahan ajar. Komunikasi tidak akan berjalan tanpa bantuan sarana penyampai pesan atau media. Bentuk-bentuk stimulus yang dapat digunakan sebagai media di antaranya adalah hubungan atau interaksi manusia, realita, gambar bergerak atau tidak, tulisan, dan suara yang direkam (Ena, 2007).

Untuk mengatasi kendala tersebut, maka penulis mecoba melakukan perbaikan pembelajaran menggunakan media video pembelajaran. Video merupakan serangkaian gambar gerak yang disertai suara yang membentuk suatu kesatuan yang dirangkai menjadi alur, dengan pesan-pesan di dalamnya untuk ketercapaian tujuan pembelajaran yang disimpan dengan proses penyimpanan pada media pita atau disk 
(Arsyad, 2004:36 dalam Rusman dkk 2011:218).Video merupakan media audio visual yang menampilkan gerak (Sadiman, 2010:74).

Berdasarkan uraian diatas, penulisakan mencoba melakukan penelitian dengan judul Peningkatan Hasil Belajar Siswa Melalui Penggunaan Media video Pembelajaran Pada Pembelajaran Daring Tema 3 Kelas V di SDN 2 Dlepih Tirtomoyo Tahun Pelajaran 2020/2021. Tujuan penelitian ini adalah meningkatkan hasil belajar siswa pada materi Tema 3 Sub Tema 2 Pembelajaran 2 menggunakan media video pembelajaran.

\section{METODE}

Penelitian ini merupakan penelitian tindakan kelas (PTK) kolaboratif yang dilaksanakan dalam dua siklus, setiap siklus terdiri dari tahap perencanaan, pelaksanaan, observasi, dan refleksi. Subjek penelitian ini adalah peserta didik kelas $\mathrm{V}$ di SDN 2 Dlepih Tirtomoyo Tahun Pelajaran 2020/2021 yang berjumlah 10 peserta didik.

Data yang dianalisis berupa data kualitatif yaitu penggunaan media video pembelajaran dan data kuantitatif yaitu hasil belajar tematik peserta didik. Teknik pengumpulan data menggunakan observasi dan tes. Uji validitas data menggunakan triangulasi teknik dan triangulasi sumber. Analisis data meliputi reduksi data, penyajian data, dan penarikan kesimpulan.

\section{HASIL DAN PEMBAHASAN}

Berdasarkan analisis hasil penelitian yang telah diuraikan maka pembahasan pada penelitian ini sebagai berikut..

\section{Penggunaan Media video Pembelajaran}

Hasil penelitian menunjukkan peningkatan penggunakan video pembelajaran yang dilakukan oleh guru. Terilhat pada tabel berikut.

Tabel 1. Peningkatan Penggunakan Media video Pembelajaran

\begin{tabular}{lccc}
\hline \multicolumn{1}{c}{ Aspek } & \multicolumn{3}{c}{ Skor Rata-rata } \\
\hline $\begin{array}{l}\text { Keterampilan mengorganisasi sumber } \\
\text { belajar dan/atau bahan ajar }\end{array}$ & Siklus I & Siklus II & Siklus III \\
$\begin{array}{l}\text { Kemampuan menggunakan teknologi } \\
\text { informasi dalam pembelajaran }\end{array}$ & 3 & 3 & 3 \\
$\begin{array}{l}\text { Keterampilan menggunakan media } \\
\text { video pembelajaran, menerapkan }\end{array}$ & 3 & 4 & 4 \\
$\begin{array}{l}\text { langkah-langkah (sintaks) pemanfaatan } \\
\text { Media video Pembelajaran }\end{array}$ & 3 & 4 & 4 \\
$\begin{array}{l}\text { Mengintegrasikankemampuan critical } \\
\text { thinking, creative thinking, reflective } \\
\text { thinking dan decision making ke dalam } \\
\text { kegiatan belajarmelalui inquiry based } \\
\begin{array}{l}\text { activities } \\
\text { Keterampilan melakukan penilaian } \\
\text { proses }\end{array}\end{array}$ & 3 & 3 & 4 \\
$\begin{array}{l}\text { Keterampilan melakukan penilaian hasil } \\
\text { belajar berbasis HOTS }\end{array}$ & 3 & 3 & 3 \\
\hline
\end{tabular}

Dari data observasi yang diperoleh pada tabel di atas bahwa aktivitas mengajar atau kegiatan mengajar guru (peneliti) mengalami peningkatan dari siklus I ke siklus II hingga Siklus III. 


\section{Hasil Belajar pada materi rumus dan fungsi Microsoft excel}

Hasil penelitian menunjukkan peningkatan hasil belajar pada materi Tema 3

Sub Tema 2 Pembelajaran ke-2. Terilhat pada tabel berikut.

Tabel 2. Peningkatan Hasil Belajar Siswa

\begin{tabular}{lccc}
\hline \multicolumn{1}{c}{ Nilai } & \multicolumn{3}{c}{ Jumlah Siswa } \\
\hline 100 & Siklus I & Siklus II & Siklus III \\
90 & 0 & 0 & 3 \\
80 & 1 & 0 & 2 \\
70 & 1 & 2 & 0 \\
65 & 4 & 6 & 5 \\
60 & 1 & 1 & \\
50 & 1 & 1 & 0 \\
40 & 0 & 0 & 0 \\
30 & 1 & 0 & 0 \\
Jumlah & 1 & 0 & 0 \\
Rata-rata & $\mathbf{1 0}$ & $\mathbf{1 0}$ & $\mathbf{1 0}$ \\
Tuntas & $\mathbf{6 4 , 5}$ & $\mathbf{7 0 , 5}$ & $\mathbf{8 3}$ \\
\hline
\end{tabular}

Peningkatan hasil belajar tematik peserta didik pada materi Tema 3 Sub Tema 2 Pembelajaran 2l diukur dengan menggunakan teknik tes hasil belajar dengan instrument soal evaluasi menggunakan google form. Teknik pengumpulan data hasil belajar peserta didik diterapkan disetiap pertemuan setelah dilakukan proses pembelajaran.

Penggunaan media video pembelajaran dapat meningkatkan hasil belajar peserta didik di kelas V SDN 2 Dlepih secara signifikan. Pada hasil Penilaian sebelumnya terdapat 7 dari 10 peserta didik yang belum mencapai KKM dengan persentase ketuntasan hasil belajar hanya 30\%. Setelah dilakukan tindakan, persentase ketuntasan hasil belajar pada siklus I meningkat menjadi $70 \%$. Pada siklus II terjadi peningkatan kembali menjadi $90 \%$ dan siklus ke III mencapai $100 \%$. Pada siklus I belum mencapai indikator kinerja penelitian yang ditetapkan. Hasil belajar pada siklus I telah mencapai indikator kinerja penelitian dan terus meningkat pada siklus II. Pada siklus III, ketuntasan hasil belajar peserta didik telah mencapai $100 \%$ dengan KKM 70 sehingga pelaksanaan tindakan dapat dihentikan.

Berdasarkan analisis hasil belajar peserta didik setelah pelaksanaan tindakan, dapat diambil kesimpulan bahwa penggunaan media video pembelajaran dapat meningkatkan hasil belajar tematik pada materi Tema 3 Sub Tema 2 Pembelajaran ke 2. Hal ini sesuai dengan hasil penelitian yang dilakukan oleh Ricka Tesi Muskania, Siti Badariah, dan Mansur Mansur yang membuktikan bahwa penggunaan media video scribe dalam pembelajaran tematik dapat meningkatkan hasil belajar siswa di SD secara signifikan.

Hasil penelitian ini sejalan dengan pendapat ahli menyatakan bahwa,"video sebagi salah satu penunjang keberhasilan dalam proses pembelajaran" (Arsyad, 2014: 9). Riyana (2012:8) menyatakan bahwa, "Melalui media video, seseorang mampu memahami pesan pembelajaran secara lebih bermakna sehingga informasi yang disampaikan melalui media tersebut dipahami secara utuh, sehingga dengan sendirinya informasi akan tersimpan dalam memori jangka panjang". 


\section{SIMPULAN}

Uraian hasil Penelitian pada Penelitian Tindakan Kelas dan pembahasan pada bab sebelumnya yang berjudul Peningkatan Minat Belajar Siswa melalui Penggunaan Media video Pembelajaran pada Pembelajaran Daring Tema 3 Kelas V di SDN 2 Dlepih Tirtomoyo Tahun Pelajaran 2020/2021. Dapat diambil kesimpulan sebagai berikut:

(1) Dalam penelitian tindakan kelas ini peneliti meneliti tentang hasil belajar siswa.(2) Hasil belajar siswa sebelum menggunakan Media video Pembelajaran pada Tema 3 Sub Tema 2 Pembelajaran 2 materi Gangguan pada organ pencernaan dan Bahasa Iklan memiliki hasil belajar kelas dengan rata-rata sebesar 53 dengan ketuntasan kelas $30 \%$. Dalam hal ini hasil belajar peserta didik masih di bawah indikator keberhasilan dan ingin dilakukan perubahan. (3) Berdasarkan hasil penelitian pada siklus I, siklus II, dan siklus III setelah diterapkannya Model Pembelajaran dengan menggunakan Media video Pembelajaran dapat meningkatkan hasil belajar peserta didik pada Tema 3 Sub Tema 2 Pembelajaran 2 materi Gangguan pada organ pencernaan ddan Bahasa Iklan di kelas V SDN 2 Dlepih, Tirtomoyo, Wonogiri. Hal ini dapat dibuktikan dengan hasil belajar peserta didik yang meningkat setelah diterapkannya Model Pembelajaran menggunakan Media video Pembelajaran. Pada tahap Pra Siklus rata-rata hasil belajar 53 dengan ketuntasan klasikal 30\%. Pada Siklus I rata-rata 64,5 dengan ketuntasan klasikal 70\%. Pada Siklus II rata-rata 70,5 dengan ketuntasan klasikal mencapai 90\%. Dan pada siklus III Tuntas 100\% dengan rata-rata 83 .

\section{DAFTAR PUSTAKA}

Arikunto, Suhardjono, Supardi. 2006. Penelitian Tindakan Kelas. Jakarta: Bumi Aksara

Arsyad, A. 2014. Media Pembelajaran. Jakartara: Raja Grafindo Persada.

Ena, O. T. 2007. Membuat Media Pembelajaran Interaktif dengan Piranti LunakPresentasi, (Online), (http:// www. ialf. edu/ kipbipa/papers/oudateda/Ena.doc), diakses 7 Oktober 2020.

Kadir, Abd dan Asrohah, Hanun. 2014. Pembelajaran Tematik. (Jakarta: PT Raja Grafindo Persada).

Kasihani Kasbolah FS. (1998). Penelitian Tindakan Kelas(PTK). Jakarta: Depdikbud.

Mulyani Sumantri \& Johar Permana. (1999). Strategi Belajar Mengajar. Jakarta: Depdiknas.

Munadi, Yudhi. 2018. Media Pembelajaran: Sebuah Pendekatan Baru. (Jakarta: Gaung Persada Press

Nana Sudjana. (2005). Penilaian Hasil Proses Belajar Mengajar. Bandung: PT Remaja Rosdakarya

Rochiati Wiriatmadja. 2005. Metode Penelitian Tindakan Kelas. Bandung: Rosda Karya

Riyana, C. (2008). Peranan teknologi dalam pembelajaran. Universitas Indonesia, Jakarta.

Sadiman, A. S. (2011). Media Pendidikan. Jakarta: Rajawali Pers. 